\title{
Guide to the Changes between the 2009 and 2012 International Energy Conservation Code
}

\section{TS Mapes \\ DR Conover}

May 2012

Pacific Northwest

NATIONAL LABORATORY

Proudly Operated by Battelle Since 1965 


\title{
DISCLAIMER
}

This report was prepared as an account of work sponsored by an agency of the United States Government. Neither the United States Government nor any agency thereof, nor Battelle Memorial Institute, nor any of their employees, makes any warranty, express or implied, or assumes any legal liability or responsibility for the accuracy, completeness, or usefulness of any information, apparatus, product, or process disclosed, or represents that its use would not infringe privately owned rights. Reference herein to any specific commercial product, process, or service by trade name, trademark, manufacturer, or otherwise does not neeessarily constitute or imply its endorsement, recommendation, or favoring by the United States (iovernment or any agency thereof, or Battelle Memorial Institute. The views and opinions of authors expressed herein do not necessarily state or rellect those of the United States (iovernment or any agency thereof.

\author{
PACIFIC NORTIWEST NATIONAL LABORATORY \\ operated by \\ BATIFII.F: \\ for the \\ UNITED STATES DEPARTMENT OF ENERGY \\ under Contract i)H:-ACO5-76RL.01830
}

Printed in the IInited States of America

Available to DOE and DOE contractors from the

Office of Scientific and Technical Information,

P.O. Box 62, Oak Ridge. TN 37831-0062:

ph: (865) 576-\$401

fix: (865) 576-5728

email: reports adonis,osti.gov

\begin{abstract}
Available to the public from the National Technical Information Service. U.S. Department of Commerce, 5285 Port Royal Rul.. Springfield, VA 22161 ph: $(\mathbf{8 0 0 )}$ 553-6847 fas: (703) 605-6900 email: orders.antis.fellworld.gov

online ordering: http:/www.ntis.gov/ordering.htm
\end{abstract}




\section{Guide to the Changes between the 2009 and 2012 International Energy Conservation Code}

TS Mapes

DR Conover

May 2012

Prepared for

the U.S. Department of Energy

under Contract DE-AC05-76RL01830

Pacific Northwest National Laboratory

Richland, Washington 99352 


\section{Acronyms}

\begin{tabular}{|c|c|}
\hline AAMA & American Architectural Manufacturers Association \\
\hline ACCA & Air Conditioning Contractors of America \\
\hline $\mathrm{ACH}$ & air changes per hour \\
\hline AHAM & Association of Home Appliance Manufacturers \\
\hline AHRI & Air-Conditioning, Heating, and Refrigeration Institute \\
\hline AMCA & Air Movement and Control Association \\
\hline ANSI & American National Standards Institute \\
\hline ARI & Air-Conditioning and Refrigeration Institute \\
\hline ASHRAE & American Society of Heating, Refrigerating and Air-Conditioning Engineers \\
\hline BECP & Building Energy Codes Program \\
\hline COP & coefficient of performance \\
\hline CSA & Canadian Standards Association \\
\hline CTI & Cooling Technology Institute \\
\hline DASMA & Door and Access Systems Manufacturers Association \\
\hline DOE & U.S. Department of Energy \\
\hline EER & energy efficiency ratio \\
\hline HVAC & Heating, ventilation, and air conditioning \\
\hline IBC & International Building Code \\
\hline ICC & International Code Council \\
\hline IECC & International Energy Conservation Code \\
\hline IEER & integrated energy efficiency ratio \\
\hline IESNA & Illuminating Engineering Society \\
\hline IMC & International Mechanical Code \\
\hline IPLV & integrated part load value \\
\hline IRC & International Residential Code \\
\hline ISO & International Organization for Standardization \\
\hline NFRC & National Fenestration Rating Council \\
\hline NPLV & non-standard part load value \\
\hline NR & no requirement \\
\hline $\mathrm{PF}$ & performance factor \\
\hline SEER & seasonal energy efficiency ratio \\
\hline SHGC & solar heat gain coefficients \\
\hline VAV & Variable air volume \\
\hline VT & Visible transmittance \\
\hline WDMA & Window \& Door Manufacturers Association \\
\hline
\end{tabular}




\section{Executive Summary}

The International Code Council (ICC) published the 2012 International Energy Conservation Code ${ }^{\circledR}$ (IECC) in early 2012. The 2012 IECC is based on revisions, additions, and deletions to the 2009 IECC that were considered during the ICC code development process conducted in 2011. Solid vertical lines, arrows, or asterisks printed in the 2012 IECC indicate where revisions, deletions, or relocations of text respectively were made to 2009 IECC. Although these marginal markings indicate where changes have been made to the code, they do not provide any further guidance, leaving the reader to consult and compare the 2009 and 2012 IECC for more detail.

The U.S. Department of Energy (DOE) Building Energy Codes Program (BECP) created this guide to help those interested in energy codes compare where and how the 2009 and 2012 IECC documents differ. Key changes to the code are summarized on the following page(s). Additional changes are summarized in the table that follows.

This document is intended only as a cursory overview of the differences between the 2009 and the 2012 IECC. It does not provide the text of the codes, and should not be considered a stand-alone reference to code requirements. Readers are encouraged to refer to the 2009 and 2012 IECC texts for greater detail as needed. Revisions, additions and deletions between codes are noted in this document as R, A, or D, in the revision type column.

Please note that BECP made every effort to avoid language that inferred opinions or judgments of these provisions. Any interpretation of such judgment is purely coincidental and not the intent of the authors. 


\subsection{Key Changes}

Key changes between the 2009 and 2012 IECC are provided below. A change may be considered key if it raises the level of stringency of the code, or if it has a positive impact on the implementation of, or compliance with, the code. The distinction between "key" and "not key" was made by the authors and is not intended to diminish the significance of any changes not noted.

\subsection{All Building Types}

- The IECC has been reformatted so that the provisions for residential and commercial buildings completely stand alone with their own separate administrative provisions, definitions, general provisions, climate zones, and reference standards.

- The provisions for both residential and commercial opaque thermal envelope components have been increased in stringency in most cases.

\subsection{Commercial Buildings}

- The table covering fenestration in commercial buildings has been simplified to define all fenestration as being fixed, operable, or an entrance door. The distinction between framing materials, thermal breaks, and curtain walls/storefronts with respect to thermal requirements has been removed. In some cases only residential criteria were modified. For example, solar heat gain coefficients (SHGC) were raised moderately for residential buildings but were not raised for commercial buildings. In addition, many of the U-factors applicable to skylights have been reduced.

- The allowable percentage of skylight area as a function of roof area has been increased from 3\% to $5 \%$ of total roof area. Additionally, in certain building types (e.g., offices, convention centers over $10,000 \mathrm{ft}^{2}$ with ceilings more than $15 \mathrm{ft}$ high), at least half of the floor area must be in a daylighting zone under skylights (with several exceptions allowed).

- Vertical fenestration area is now limited to $30 \%$ of above-grade wall area. The previous maximum of $40 \%$ is still allowed in Climate Zones 1-6, provided half of the conditioned floor is in a daylight zone, controls are installed, and the VT/SHGC ratio is at least 1.1.

- Visible transmittance is now used in several provisions for both vertical fenestration and skylights. In particular, a VT/SHGC ratio is one of three conditions used to increase the fenestration area maximum from $30 \%$ to $40 \%$.

- Air barrier requirements have been added such that a continuous barrier is now needed throughout the building envelope in other than Climate Zones 1-3. The barrier must be sealed at all seams and joints, and lighting fixtures and other recesses must be treated to maintain that barrier.

- HVAC system piping insulation requirements have become more stringent. These requirements now also rely on pipe diameter and fluid temperature.

- Air system economizers are required in more climate zones and at a lower threshold (33K Btu/h instead of $54 \mathrm{~K} \mathrm{Btu} / \mathrm{h})$.

- A space-by-space method for determining allowable lighting power limits based on ASHRAE 90.110 was added. 
- A new section on building commissioning has been added. It is now necessary for a registered design professional (or agency) to develop a mechanical system commissioning plan, and provide evidence of commissioning prior to the final mechanical inspection. HVAC air and water flow rates now must be balanced, and equipment, controls, and lighting must be performance tested.

\subsection{Residential Buildings}

- Added clarification that sunrooms enclosing conditioned spaces must meet the thermal envelope provisions of the 2012 IECC unless they are thermally isolated from the rest of the building.

- All residential buildings must be subjected to a blower door test to determine the air leakage rate and must not exceed the number of air changes per hour (ACH), either 5 or 3 , prescribed as a function of climate zone.

- Hot water piping must now be insulated to at least R-3 with some exceptions.

- The minimum number of high-efficacy electrical lighting sources was changed from $50 \%$ of lamps in permanent fixtures to $75 \%$ of lamps in permanent fixtures or $75 \%$ of the permanent fixtures. 


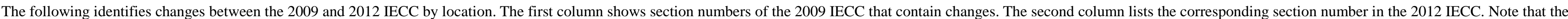

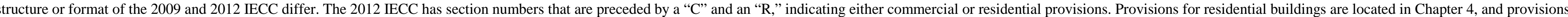
for commercial buildings are located in Chapter 5 of the 2009 IECC.

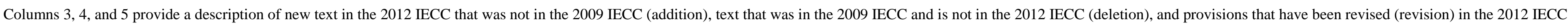
Section numbers in the 2009 IECC that are not included the first column or described elsewhere in the table remain unchanged other than being renumbered to be consistent with the new "C" and " $\mathrm{R}$ " designation.

\begin{tabular}{|c|c|c|c|}
\hline 2009 IECC & 2012 IECC & CHANGES & $\begin{array}{l}\text { REVISION } \\
\text { TYPE }\end{array}$ \\
\hline 101.2 Scope & $\begin{array}{l}\text { C101.2 Scope } \\
\text { R101.2 Scope } \\
\end{array}$ & $\begin{array}{l}\text { The } 2012 \text { IECC separated the residential and commercial portions into two distinct, separate, stand-alone "codes." Both residential and commercial scopes were revised to } \\
\text { include building sites in addition to systems and equipment associated with buildings and building sites. }\end{array}$ & $\mathrm{R}$ \\
\hline 101.3 Intent & C101.3 Intent & The intent of the 2009 IECC is "effective use of energy." The 2012 IECC adds "conservation of energy" and "over the useful life of the building" to that intent. & $\mathrm{R}$ \\
\hline 202 Definitions & C202 Definitions & & \\
\hline Building & Building & $\begin{array}{l}\text { The } 2012 \text { IECC expanded the definition beyond the building to include mechanical, service water heating, electrical, and lighting systems that are on the building site and } \\
\text { support the building. }\end{array}$ & $\mathrm{R}$ \\
\hline$\overline{-}$ & Building commissioning & Newly defined term - Verifying and documenting that a building operates according to the owner's requirements and to minimum code requirements. & A \\
\hline$\overline{\overline{-}}$ & Building entrance & Newly defined term - Any portal with access to the building from the outside. & $\mathrm{A}$ \\
\hline- & Building site & Newly defined term - A continuous area of land owned by a single entity. & A \\
\hline Building thermal envelope & Building thermal envelope & Editorial clarification regarding boundaries between conditioned space and any exempt of unconditioned space. & $\mathrm{R}$ \\
\hline- & Coefficient of performance (COP) - Cooling & Newly defined term - The ratio of heat removed to energy input for a complete refrigeration system or specific part of that system. & A \\
\hline$\overline{-}$ & Coefficient of performance (COP) - Heating & Newly defined term - The ratio of heat delivered to energy input for a complete heating system or specific part of that system, including the compressor and auxiliary heat. & $\mathrm{A}$ \\
\hline$\overline{-}$ & Continuous air barrier & Newly defined term - Building materials or assemblies that restrict air passage through the building envelope. & A \\
\hline$\overline{-}$ & Demand recirculation water system & Newly defined term - A system that primes hot water piping with hot water upon demand. & $\mathrm{A}$ \\
\hline Dwelling unit & [B] Dwelling unit & $\begin{array}{l}\text { Added [B] in front of the definition to indicate that changes to the definition are under the IBC code change agenda and not the purview of the IECC Commercial } \\
\text { Committee. (Note - this change was not made in the IECC residential provisions.) }\end{array}$ & $\mathrm{R}$ \\
\hline- & Dynamic glazing & Newly defined term - A fenestration product capable of changing its performance properties, such as U-factor, SHGC, or VT. & A \\
\hline$\overline{-}$ & Enclosed space & Newly defined term - A three-dimensional area surrounded by solid surfaces or operable devices (e.g., doors, windows). & A \\
\hline Energy recovery ventilation & [M] Energy recovery ventilation & $\begin{array}{l}\text { Added [M] in front of the definition to indicate that changes to the definition are under the IMC code change agenda and not the purview of the IECC Commercial } \\
\text { Committee. }\end{array}$ & $\mathrm{R}$ \\
\hline$\overline{-}$ & Equipment room & Newly defined term - Any room whose equipment, machinery, or pumps support the building. & A \\
\hline- & Fenestration product, field-fabricated & $\begin{array}{l}\text { Newly defined term - Frames, jambs, and other fenestration parts created from materials near the site that were not originally intended for that purpose (e.g., the use of } \\
\text { excess lumber to create window frames). This does not, however, include site-built parts that were created in factories for the fenestration purpose and then assembled on } \\
\text { site. }\end{array}$ & A \\
\hline- & Fenestration product, site-built & Newly defined term - A fenestration product made from parts created in factories for the purpose of fenestration and assembled on site. & A \\
\hline$\overline{-}$ & Furnace electricity ratio & Newly defined term - The ratio of furnace electricity use to total furnace energy use. ER $=3.412 \mathrm{E}_{\mathrm{AE}} /\left(1000 \mathrm{E}_{\mathrm{F}}+3.412 \mathrm{E}_{\mathrm{AE}}\right)$. & $\mathrm{A}$ \\
\hline$\overline{-}$ & General lighting & Newly defined term - Lighting that remains at a uniform level over a given area. This does not include decorative lighting and task-specific lighting. & $\overline{\mathrm{A}}$ \\
\hline$\overline{-}$ & Integrated part load value (IPLV) & Newly defined term - Unlike EER or COP, which describe efficiency at full-load conditions, IPLV describes efficiency at various capacities. & A \\
\hline$\overline{-}$ & Non-standard part load value (NPLV) & Newly defined term - Calculated part-load value that does not use the standard ARI rating conditions. & A \\
\hline- & On-site renewable energy & Newly defined term - Any system located on site that provides energy from a renewable source (e.g., solar, wind, geothermal, tidal, biomass). & $\mathrm{A}$ \\
\hline Residential building & Residential building & Added detached one and two-family dwellings and multiple one-family dwellings (e.g., townhouses). & $\mathrm{R}$ \\
\hline Skylight & Skylight & Changed defining angle of skylights from at least 15 degrees from vertical to less than 60 degrees from horizontal. & $\mathrm{R}$ \\
\hline Sleeping unit & [B] Sleeping unit & $\begin{array}{l}\text { Added [B] in front of the definition to indicate that changes to the definition are under the IBC code change agenda and not the purview of the IECC Commercial } \\
\text { Committee. }\end{array}$ & $\mathrm{R}$ \\
\hline Storefront & Storefront & Added "with or without mulled windows and doors" to the end of the definition. & $\mathrm{R}$ \\
\hline Ventilation & [M] Ventilation & $\begin{array}{l}\text { Added }[\mathrm{M}] \text { in front of the definition to indicate that changes to the definition are under the IMC code change agenda and not the purview of the IECC Commercial } \\
\text { Committee. (Note - this change was not made in the IECC residential provisions.) }\end{array}$ & $\mathrm{R}$ \\
\hline Ventilation air & [M] Ventilation air & $\begin{array}{l}\text { Added [M] in front of the definition to indicate that changes to the definition are under the IMC code change agenda and not the purview of the IECC Commercial } \\
\text { Committee. (Note - this change was not made in the IECC residential provisions.) }\end{array}$ & $\mathrm{R}$ \\
\hline$-\overline{-}$ & Visible transmittance & Newly defined term - A number from zero to one that describes the ratio of visible light to total incident light passing through a fenestration product. & $\mathrm{A}$ \\
\hline 303.1.3 Fenestration product rating & C303.1.3 Fenestration product rating & Expanded ratings to include VT for fenestration products whose SHGC ratings are determined by the NFRC 200. & $\mathrm{R}$ \\
\hline $\begin{array}{l}\text { Table 303.1.3(3) Default glazed } \\
\text { fenestration SHGC }\end{array}$ & $\begin{array}{l}\text { Table C303.1.3(3) Default glazed } \\
\text { fenestration SHGC and VT }\end{array}$ & Added VT requirements to the table. & $\mathrm{R}$ \\
\hline
\end{tabular}




\begin{tabular}{|c|c|c|c|}
\hline 2009 IECC & 2012 IECC & CHANGES & $\begin{array}{l}\text { REVISION } \\
\text { TYPE }\end{array}$ \\
\hline $\begin{array}{l}\text { 501.1 Scope } \\
\text { 501.2 Application }\end{array}$ & $\begin{array}{l}\text { C401.1 Scope } \\
\text { C401.2 Application }\end{array}$ & $\begin{array}{l}\text { Changed the caveats related to compliance. ANSI/ASHRAE/IES Standard 90.1-2010 remains a "deemed-to-comply" option. Alternatively, all commercial provisions of the } \\
\text { IECC must be satisfied. However, the } 2012 \text { IECC has added three new provisions (Section C406), one of which must also be chosen. The total building performance } \\
\text { compliance path remains, although instead of the proposed design having an annual energy cost less than the standard reference design building, that criterion has been } \\
\text { reduced to } 85 \% \text { of the standard reference design building (although the provisions in } 506.3 \text { of the } 2009 \text { IECC have not been similarly changed in Section C407.3 of the } \\
2012 \text { IECC). }\end{array}$ & $\mathrm{R}$ \\
\hline- & C401.2.1 Application to existing buildings & $\begin{array}{l}\text { Added a new subsection to provide that additions, alterations, and repairs to existing buildings meet either ASHRAE 90.1-10, or the envelope, HVAC, service water } \\
\text { heating, and lighting provisions of the IECC. }\end{array}$ & A \\
\hline 502.1 General (Prescriptive) & C402.1 General (Prescriptive) & $\begin{array}{l}\text { Added criteria to clarify that the building envelope was to meet either the insulation and fenestration criteria, or could use the U-factor alternative criteria in lieu of meeting } \\
\text { the required R-values for insulation. }\end{array}$ & $\mathrm{R}$ \\
\hline $\begin{array}{l}502.2 \text { Specific insulation requirements } \\
\text { (Prescriptive) }\end{array}$ & $\begin{array}{l}\text { C402.2 Specific insulation requirements } \\
\text { (Prescriptive) }\end{array}$ & $\begin{array}{l}\text { Added provisions for the installation of continuous insulation board that contain a reference to the chapter on General Requirements covering installation of insulation and } \\
\text { requiring multiple layers of insulation board to have the joints staggered unless the board manufacturer's installation instructions specifically cover installation of multiple } \\
\text { layers of insulation board. }\end{array}$ & $\mathrm{R}$ \\
\hline 502.2.1 Roof assembly & C402.2.1 Roof assembly & $\begin{array}{l}\text { Added provisions covering insulation of skylight curbs: the lesser of R-5 or the R-value of the roof insulation that is entirely above the roof deck unless the skylight curb is } \\
\text { included as a component of the skylight assembly that is rated according to NFRC } 100 \text {. }\end{array}$ & $\mathrm{R}$ \\
\hline- & $\begin{array}{l}\text { C402.2.1.1 Roof solar reflectance and } \\
\text { thermal emittance }\end{array}$ & $\begin{array}{l}\text { Added provisions addressing minimum solar reflectance and thermal emittance of roofs in Climate Zones } 1-3 \text { that have a slope less than } 2 \text { in } 12 \text { and a number of exceptions } \\
\text { from those provisions for certain types of roof surfaces or those that are not exposed to solar radiation at certain times. }\end{array}$ & A \\
\hline 502.2.3 Above-grade walls & $\begin{array}{l}\text { C402.2.3 Thermal resistance of above-grade } \\
\text { walls }\end{array}$ & Editorial change in subsection title. & $\mathrm{R}$ \\
\hline 502.2.4 Below-grade walls & $\begin{array}{l}\text { C402.2.4 Thermal resistance of below-grade } \\
\text { walls }\end{array}$ & Editorial change in subsection title. & $\mathrm{R}$ \\
\hline $\begin{array}{l}\text { 502.2.5 Floors over outdoor air or } \\
\text { unconditioned space }\end{array}$ & $\begin{array}{l}\text { C402.2.5 Floors over outdoor air or } \\
\text { unconditioned space }\end{array}$ & Editorial change to criteria for mass floors from being "at least" to "not less than" stated weights. & $\mathrm{R}$ \\
\hline 502.2.6 Slabs on grade & C402.2.6 Slabs on grade & $\begin{array}{l}\text { Added provisions to limit scope to slabs in contact with the ground and an exception to limit that coverage to those } 24 \text { in. or less below finished grade. Also added } \\
\text { provisions that insulation extending away from the building must be protected by pavement or at least } 10 \text { in. of soil. }\end{array}$ & $\mathrm{R}$ \\
\hline- & $\begin{array}{l}\text { C402.2.8 Insulation of radiant heating } \\
\text { systems }\end{array}$ & Added provisions to ensure that radiant heating systems for indoor space heating are insulated with at least R-3.5. & A \\
\hline $\begin{array}{l}\text { Table 502.1.2 Building envelope } \\
\text { requirements opaque element, } \\
\text { maximum U-factors }\end{array}$ & $\begin{array}{l}\text { Table C402.1.2 Opaque thermal envelope } \\
\text { assembly requirements }\end{array}$ & $\begin{array}{l}\text { No row or column headings changed. Some requirements increased, some stayed the same, and none decreased in stringency. Added a footnote to allow values from } \\
\text { ASHRAE 90.1-10 Appendix A to be used where the construction in question matches that covered in Appendix A. }\end{array}$ & $\mathrm{R}$ \\
\hline $\begin{array}{l}\text { Table 502.2(1) Building envelope } \\
\text { requirements - Opaque assemblies }\end{array}$ & $\begin{array}{l}\text { Table C402.2 Opaque thermal envelope } \\
\text { requirements }\end{array}$ & $\begin{array}{l}\text { No row or column headings changed. Some requirements increased in stringency, some remain unchanged, and none decreased in stringency. Changed the footnote } \\
\text { referring to metal building assembly thermal properties from a table in the IECC to ASHRAE 90-1-10 Appendix A. }\end{array}$ & $\mathrm{R}$ \\
\hline $\begin{array}{l}\text { Table 502.2(2) Building envelope } \\
\text { requirements - Opaque assemblies }\end{array}$ & - & Table deleted and replaced by reference to ASHRAE 90-1-10 Appendix A. & $\mathrm{D}$ \\
\hline 502.3 Fenestration (Prescriptive) & C402.3 Fenestration (Prescriptive) & Added reference to new provision that daylighting controls specified in Section C402.3 must satisfy the lighting section of the 2012 IECC (Section C405). & $\mathrm{R}$ \\
\hline C402.3.1 Maximum area & C402.3.1 Maximum area & $\begin{array}{l}\text { The percentage limit of vertical fenestration area as a function of above-grade wall area has been reduced from } 40 \% \text { to } 30 \% \text { and the percentage limit of skylight area as a } \\
\text { function of roof area remains unchanged at } 3 \% \text {. New provisions have been added that allow the } 30 \% \text { to increase to } 40 \% \text {, and the } 3 \% \text { to increase to } 5 \% \text {. }\end{array}$ & $\mathrm{R}$ \\
\hline- & $\begin{array}{l}\text { C402.3.1.1 Increased vertical fenestration } \\
\text { area with daylighting controls }\end{array}$ & $\begin{array}{l}\text { Added provisions that allow up to } 40 \% \text { fenestration area to above-grade wall area in Climate Zones 1-6 when at least } 50 \% \text { of the conditioned floor area is within a daylight } \\
\text { zone that also has daylighting controls and the VT of the fenestration, when within the scope of NFRC } 200 \text {, is at least } 10 \% \text { greater than the SHGC. }\end{array}$ & A \\
\hline - & $\begin{array}{l}\text { C402.3.1.2 Increased skylight area with } \\
\text { daylighting controls }\end{array}$ & $\begin{array}{l}\text { The percentage limit of skylight area as a function of roof area can be increased from over } 3 \% \text { to up to } 5 \% \text { when the daylight zone under the skylights has automatic } \\
\text { daylighting controls. }\end{array}$ & A \\
\hline- & $\begin{array}{l}\text { C402.3.2 Minimum skylight fenestration } \\
\text { area }\end{array}$ & $\begin{array}{l}\text { Enclosed spaces greater than } 10,000 \mathrm{ft}^{2} \text { with ceilings higher than } 15 \mathrm{ft} \text { that are being used for one of several special purposes (e.g., office, lobby, atrium) must have at least } \\
\text { half of the floor area in a daylighting zone and have a minimum skylight area percentage based on skylight VT or effective aperture. Exceptions are made depending on } \\
\text { climate zone, lighting power densities, blockage of direct sunlight on the roof, and areas where the daylight zone is more than } 50 \% \text { of the enclosed floor area. }\end{array}$ & A \\
\hline- & $\begin{array}{l}\text { C402.3.2.1 Lighting controls in daylight } \\
\text { zones under skylights }\end{array}$ & $\begin{array}{l}\text { All lighting in the daylighting zone must be controlled by multi-level controls that comply with Section C405.2.2.3.3. Exceptions are made depending on climate zone, } \\
\text { lighting power densities, blockage of direct sunlight on the roof, and areas where the daylight zone is more than 50\% of the enclosed floor area. }\end{array}$ & A \\
\hline- & C402.3.2.2 Haze factor & $\begin{array}{l}\text { Skylights in certain areas (e.g., office, storage, automotive service) must have a glazing material or diffuser that creates a haze factor greater than } 90 \% \text { according to } \\
\text { ASTM D 1003. An exception is made for skylights using baffles or skylight geometry to exclude direct sunlight from entering the area. }\end{array}$ & A \\
\hline 502.3.3 Maximum U-factor and SHGC & C402.3.3 Maximum U-factor and SHGC & For windows and glass doors having different PF values, the option of using an area-weighted PF value has been removed. Each must be evaluated separately. & $\mathrm{R}$ \\
\hline $\begin{array}{l}\text { Table } 502.3 \text { Building envelope } \\
\text { requirements - fenestration }\end{array}$ & $\begin{array}{l}\text { Table C402.3 Building envelope } \\
\text { requirements -fenestration }\end{array}$ & $\begin{array}{l}\text { No column headings changed. Row headings are simplified and provide for vertical fenestration U-factor for fixed and operable fenestration and entrance doors, SHGC for } \\
\text { any vertical fenestration, and U-factor and SHGC for any skylights. All U-factor and SHGC criteria were either reduced or remain the same except for the U-factor for some } \\
\text { vertical fenestration in Climate Zone 6, which was increased. }\end{array}$ & $\mathrm{R}$ \\
\hline$\overline{-}$ & C402.3.3.1 SHGC adjustment & Added new provisions to allow for the adjustment of maximum allowable fenestration SHGC values upwards based on projection factor and orientation of the fenestration. & $\mathrm{A}$ \\
\hline- & $\begin{array}{l}\text { C402.3.3.2 Increased vertical fenestration } \\
\text { and SHGC }\end{array}$ & There will be an SHGC maximum of 0.40 for all windows that are entirely placed at least $6 \mathrm{ft}$ above the finished floor in Climate Zones 1-3. & $\bar{A}$ \\
\hline$\overline{-}$ & C402.3.3.3 Increased skylight SHGC & Skylights above daylighting zones that have automated control systems will have a maximum SHGC of 0.60 in Climate Zones 1-6. & $\mathrm{A}$ \\
\hline$\overline{-}$ & C402.3.3.4 Increased skylight U-factor & Skylights above daylighting zones that have automated control systems will have a maximum U-factor of 0.90 in Climate Zones 1-3 and 0.75 in Climate Zones 4-8. & A \\
\hline
\end{tabular}




\begin{tabular}{|c|c|c|c|}
\hline 2009 IECC & 2012 IECC & CHANGES & $\begin{array}{l}\text { REVISION } \\
\text { TYPE } \\
\end{array}$ \\
\hline- & C402.3.3.5 Dynamic glazing & $\begin{array}{l}\text { For dynamic glazing, the SHGC used to comply with Section } 402.3 .3 \text { will be the lowest rated by the manufacturer, and the VT/SHGC ratio will use the highest rating for } \\
\text { each metric. Area-weighted averaging of dynamic glazing together with non-dynamic windows will not be permitted. }\end{array}$ & A \\
\hline- & C402.3.4 Area-weighted U-factor & $\begin{array}{l}\text { Area-weighted U-factors are only permitted for windows within the same product category (e.g., operable windows and fixed windows cannot be calculated together to find } \\
\text { area-weighted averages). }\end{array}$ & A \\
\hline 502.4 Air leakage & C402.4 Air leakage & $\begin{array}{l}\text { Revised the air leakage provisions by adding provisions for air barriers, adding more detail on air leakage associated with doors and access openings, and revised provisions } \\
\text { associated with fenestration air leakage, vestibules, and recessed lighting. }\end{array}$ & $\mathrm{R}$ \\
\hline- & C402.4.1 Air barriers & $\begin{array}{l}\text { The thermal building envelope must provide a continuous air barrier either inside, outside, or within the envelope assemblies or any combination thereof. Specifics are given } \\
\text { in the next several sections. Exception: Climate Zones 1-3. }\end{array}$ & A \\
\hline- & C402.4.1.1 Air barrier construction & $\begin{array}{l}\text { The continuous air barrier is expected to be: (1) across all joints and assemblies; (2) sealed at joints and changes of position or materials; and (3) compliant with } \\
\text { Section C404.2.8 where the barrier is penetrated (recessed light fixtures, etc.). However, buildings complying with Section C402.4.1.2.3 are exempt from (1) and (3). }\end{array}$ & A \\
\hline$\overline{-}$ & C402.4.1.2 Air barrier compliance options & Opaque building envelopes must meet the conditions of Sections C402.4.1.2.1-C402.4.1.2.3. & $\mathrm{A}$ \\
\hline- & C402.4.1.2.1 Materials & $\begin{array}{l}\text { A list of } 15 \text { materials (e.g., plywood, gypsum board) must be tested in accordance with ASTM E } 2178 \text { if they have an air leakage greater than } 0.004 \mathrm{cfm} / \mathrm{ft}^{2} \text { under a pressure } \\
\text { differential of } 75 \text { Pa. }\end{array}$ & $\bar{A}$ \\
\hline- & C402.4.1.2.2 Assemblies & $\begin{array}{l}\text { Material assemblies must be tested to ASTM E 2357, ASTM E 1677, and ASTM E } 283 \text { and display an average air leakage no greater than } 0.04 \mathrm{cfm} / \mathrm{ft}^{2} \text { at a pressure } \\
\text { differential of } 75 \text { Pa. Two particular assemblies-coated concrete masonry walls and a Portland cement/sand parge-need only comply to Section C402.4.1.1. }\end{array}$ & A \\
\hline- & C402.4.1.2.3 Building test & $\begin{array}{l}\text { The completed building envelope air leakage should not exceed } 0.40 \mathrm{cfm} / \mathrm{ft}^{2} \text { for a pressure differential of } 75 \text { Pa in accordance with ASTM E } 779 \text { or an equivalent method } \\
\text { approved by a code official. }\end{array}$ & A \\
\hline $\begin{array}{l}\text { 502.4.1 Window and door assemblies } \\
\text { 502.4.2 Curtain walls, storefront glazing } \\
\text { and commercial entrance doors }\end{array}$ & $\begin{array}{l}\text { C402.4.3 Air leakage of fenestration } \\
\text { Table 402.4.3 Maximum air infiltration rate } \\
\text { of fenestration assemblies }\end{array}$ & $\begin{array}{l}\text { Deleted the provisions from the } 2009 \text { IECC and replaced them with a table that lists the maximum allowable air infiltration rates for fenestration. All maximum air leakage } \\
\text { rates are reduced except certain fenestration tested to AAMA/WDMA/CSA } 101 / \mathrm{IS} .2 / \mathrm{A} 4440 \text { at } 300 \text { Pa can continue to have an air leakage rate of } 0.30 \mathrm{cfm} / \mathrm{ft} \text {. Also added air } \\
\text { leakage limits for garage doors and rolling doors and added NFRC } 400 \text { as an acceptable test standard. Provisions allowing site-constructed windows and doors to be weather } \\
\text { stripped and sealed in lieu of meeting the air infiltration rates were deleted. }\end{array}$ & $\mathrm{R}$ \\
\hline 502.4.3 Sealing of the building envelope & C402.4.2 Air barrier penetrations & $\begin{array}{l}\text { Deleted the provisions from the } 2009 \text { IECC and replaced them with new provisions addressing sealing all paths of air leakage in the air barrier at both penetrations of and } \\
\text { joints and seams in the air barrier. }\end{array}$ & $\mathrm{R}$ \\
\hline 502.4.4 Hot gas bypass limitation & C403.4.7 Hot gas bypass limitations & Provisions moved from Section 502 to Section C403 and remain unchanged. & $\mathrm{R}$ \\
\hline \multirow{4}{*}{$\begin{array}{l}\text { 502.4.5 Outdoor air intakes and exhaust } \\
\text { openings }\end{array}$} & $\begin{array}{l}\text { C402.4.4 Doors and access openings to } \\
\text { shafts, chutes, stairways, and elevator } \\
\text { lobbies }\end{array}$ & $\begin{array}{l}\text { These types of openings must meet Table } 402.4 .3 \text { or be gasketed, weatherstripped, or sealed. Exception: Door openings required by the IBC to comply to IBC Section } 715 \\
\text { or } 715.4 \text { or to UL } 1784 \text { need not comply with this section. }\end{array}$ & $\mathrm{R}$ \\
\hline & $\begin{array}{l}\text { C402.4.5 Air intakes, exhaust openings, } \\
\text { stairways and shafts }\end{array}$ & These openings must have dampers and be in accordance with Section C402.4.5.1 and Section C402.4.5.2. & $\mathrm{R}$ \\
\hline & C402.4.5.1 Stairway and shaft vents & $\begin{array}{l}\text { Must have Class I motorized dampers with a maximum leakage rate of } 4 \mathrm{cfm} / \mathrm{ft}^{2} \text { at } 249 \text { Pa when tested to AMCA 500D. Controls must be installed that open the dampers } \\
\text { when activated by a fire alarm system or when power to the dampers is interrupted. }\end{array}$ & $\mathrm{R}$ \\
\hline & C402.4.5.2 Outdoor air intakes and exhausts & $\begin{array}{l}\text { Must have Class I motorized dampers with a maximum leakage rate described in Section C402.4.5.1. Exceptions: Gravity dampers with a maximum leakage of } 20 \mathrm{cfm} / \mathrm{ft}^{2} \text { at } \\
249 \text { Pa when tested to AMCA 500D are permitted when used for exhaust or relief dampers, in buildings less than three stories above grade, buildings in Climate Zones } 1-3 \text {, } \\
\text { or where design air intake/exhaust in }<300 \mathrm{cfm} \text {. Dampers smaller than } 24 \text { in. may have a leakage up to } 40 \mathrm{cfm} / \mathrm{ft}^{2} \text {. }\end{array}$ & $\mathrm{R}$ \\
\hline 502.4.7 Vestibules & C402.4.7 Vestibules & $\begin{array}{l}\text { Added a provision that the installation of a revolving door in an entrance does not eliminate the requirement for installation of a vestibule. Changed the scope of the } \\
\text { requirement to provide a vestibule from doors separating conditioned space from the exterior to building entrances. Changed the exception for doors not intended to be used } \\
\text { by the public or intended solely for employee use to doors not intended to be used as a building entrance. Added a new definition for building entrance. }\end{array}$ & $\mathrm{R}$ \\
\hline- & C402.4.8 Recessed lighting & $\begin{array}{l}\text { Editorial change to state the limitation of } 2.0 \mathrm{cfm} \text { first and then the ASTM test standard instead of the reverse. No change in the "end state" technical requirements in the } \\
2012 \text { IECC. }\end{array}$ & A \\
\hline $\begin{array}{l}\text { 503.2.1 Calculation of heating and } \\
\text { cooling loads }\end{array}$ & $\begin{array}{l}\text { C403.2.1 Calculation of heating and cooling } \\
\text { loads }\end{array}$ & Added a sentence that the required design loads must account for building envelope, lighting, ventilation, and occupancy-related loads of the project. & $\mathrm{R}$ \\
\hline 503.2.2 Equipment and system sizing & C403.2.2 Equipment and system sizing & For clarification, heating and cooling equipment and systems capacity is defined as output capacity. & $\mathrm{R}$ \\
\hline $\begin{array}{l}\text { 503.2.3 HVAC equipment performance } \\
\text { requirements }\end{array}$ & $\begin{array}{l}\text { C403.2.3 HVAC equipment performance } \\
\text { requirements }\end{array}$ & Addition of plate-type liquid-to-liquid heat exchangers, which must meet the requirements of Table C403.2.3(9). & $\mathrm{R}$ \\
\hline 503.2.3 Exception & $\begin{array}{l}\text { C403.2.3.1 Water-cooled centrifugal chilling } \\
\text { packages }\end{array}$ & $\begin{array}{l}\text { Two equations (Equations 4-3 and 4-4) are given for equipment not designed for operation at AHRI Standard 550/590 test conditions. These equations refer to Table 6.8.1C } \\
\text { of the AHRI Standard and replace the earlier equations used in the } 2009 \text { IECC. These equations only apply to centrifugal chillers having (1) exit evaporative fluid } \\
\text { temperature } \geq 36^{\circ} \mathrm{F} ;(2) \text { exit condenser fluid temperature } \leq 115^{\circ} \mathrm{F} \text {; and (3) delta temperature for these two fluids } \geq 20^{\circ} \mathrm{F} \text { and } \leq 80^{\circ} \mathrm{F} \text {. Chillers designed to operate outside of } \\
\text { these ranges need not comply. }\end{array}$ & $\mathrm{R}$ \\
\hline Tables 503.2.3(1)-(7) & Table C403.2.3(1)-(9) & $\begin{array}{l}\text { An additional column has been added titled "Heating Section Type," which differentiates electric resistance equipment from other types in some areas of the table. Some } \\
\text { additional equipment types (e.g., through-the-wall, air-cooled) have been added, numerous quantitative changes have been made to the SEER requirements, and some test } \\
\text { procedures have changed, but otherwise these tables have the same format as in the } 2009 \text { version. Two additional tables have been added for heat rejection and heat transfer } \\
\text { equipment. }\end{array}$ & $\mathrm{R}$ \\
\hline
\end{tabular}




\begin{tabular}{|c|c|c|c|}
\hline 2009 IECC & 2012 IECC & (2) & $\begin{array}{l}\text { REVISION } \\
\text { TYPE } \\
\end{array}$ \\
\hline $\begin{array}{l}\text { Table 503.2.3(1) Minimum efficiency } \\
\text { requirements: Electrically operated } \\
\text { unitary air conditioners and condensing } \\
\text { units }\end{array}$ & $\begin{array}{l}\text { Table C403.2.3(1) Minimum efficiency } \\
\text { requirements: Electrically operated unitary } \\
\text { air conditioners and condensing units }\end{array}$ & $\begin{array}{l}\text { Added a column covering the type of heating section provided with the air conditioner. Added provisions for small-duct high-velocity air-cooled equipment and condensing } \\
\text { units over } 135 \mathrm{~K} \text { Btu/h air, water or evaporatively cooled. Minimum efficiency for air-cooled air conditioners under 65K Bth/h and for through-the-wall air-cooled units not } \\
\text { over } 30 \mathrm{~K} \text { Btu/h did not change. Minimum energy efficiency ratios for air, water, or evaporatively cooled air conditioners changed in some instances, based on part because } \\
\text { of the new distinction associated with the type of heating section and the addition in all cases of a minimum IEER as well. }\end{array}$ & $\mathrm{R}$ \\
\hline $\begin{array}{l}\text { Table 503.2.3(2) Unitary air } \\
\text { conditioners and condensing units } \\
\text { electrically operated minimum } \\
\text { efficiency requirements }\end{array}$ & $\begin{array}{l}\text { Table C403.2.3(2) Minimum efficiency } \\
\text { requirements: Electrically operated unitary } \\
\text { and applied heat pumps }\end{array}$ & $\begin{array}{l}\text { Added a column covering the type of heating section provided with the heat pump that applies to the cooling mode of air-cooled heat pumps. Added heating and cooling } \\
\text { mode provisions for single- (small) duct high-velocity air equipment. Efficiency for air-cooled cooling mode heat pumps remains unchanged or increased based on capacity } \\
\text { and all now have a minimum IERR in addition to the previous energy efficiency requirements. Water-source cooling mode provisions are unchanged. Added a rating point } \\
\text { and energy efficiency requirement (77F/13.4 EERR for groundwater source heat pumps in the cooling mode. Deleted cooling efficiency for ground source heat pumps. } \\
\text { Added new classifications and efficiency requirements for the cooling and heating modes of water source water-to-water and groundwater-source brine-to-water equipment. } \\
\text { Heating seasonal performance factor for heating mode of air-cooled under } 65 \mathrm{~K} \text { Btu/h and through-the-wall heat pumps remain unchanged. COP for heating mode of air- } \\
\text { cooled heat pumps at least } 65 \mathrm{~K} \text { Btutu/h remain unchanged for hight-temperaturer rating condition but added a new low-temperature rating condition and COP requirement. } \\
\text { Heating mode efficiency of water-source, groundwater-source, and ground-source heat pumps remain unchanged. }\end{array}$ & $\mathrm{R}$ \\
\hline $\begin{array}{l}\text { Table 503.2.3(3) Packaged terminal air } \\
\text { conditioners and packaged terminal } \\
\text { heat pumps }\end{array}$ & $\begin{array}{l}\text { Table C403.2.3(3) Minimum efficiency } \\
\text { requirements: Electrically operated } \\
\text { packaged terminal air conditioners, } \\
\text { packaged terminal heat pumps, single } \\
\text { package vertical air conditioners, single } \\
\text { vertical heat pumps, room air conditioners } \\
\text { and room air-conditioner heat pumps }\end{array}$ & $\begin{array}{l}\text { Added new minimum efficiencies for packaged terminal air conditioner and packaged terminal heat pump equipment listed in the } 2009 \text { IECC that are effective October } 18 \text {, } \\
\text { 2012. Until then, the same provisions in the } 2009 \text { IECC are retained. Also added provisions for single package vertical equipment and a number of room air conditioner } \\
\text { types effective before October 18,2012, and after that date as well based on input capacity and select test conditions. }\end{array}$ & $\mathrm{R}$ \\
\hline $\begin{array}{l}\text { Table 503.2.3(5) Boilers, gas and oil- } \\
\text { fired minimum efficiency requirements }\end{array}$ & $\begin{array}{l}\text { Table C403.2.3(5) Minimum efficiency } \\
\text { requirements: Gas and oil-fired boilers }\end{array}$ & $\begin{array}{l}\text { Revised the format of the table to focus first on type of boiler (hot water or steam) as opposed to fuel type. Combined oil-fired and boilers (residual) with all oil-fired } \\
\text { boilers. The minimum efficiency (annual fuel utilization efficiency) remains unchanged for gas and oil-fired boilers under 300K Btu/h input. All others have been revised to } \\
\text { either increase the stated thermal efficiency or combustion efficiency or change the metric from combustion to thermal efficiency and reduce the minimum efficiency. }\end{array}$ & $\mathrm{R}$ \\
\hline $\begin{array}{l}\text { Table 503.2.3(7) Water chilling } \\
\text { packages efficiency requirements }\end{array}$ & $\begin{array}{l}\text { Table C403.2.3(7) Minimum efficiency } \\
\text { requirements: Water chilling packages }\end{array}$ & $\begin{array}{l}\text { Changed the Path B values for air-cooled chillers from NR (no requirement) to NA (not applicable). The footnote in the } 2009 \text { IECC referring to chillers with leaving fluid } \\
\text { temperatures below } 40^{\circ} \mathrm{F} \text { was revised. It now states that the provisions after adjustment per the IECC do not apply to chillers with leaving temperatures less than } 36^{\circ} \mathrm{F} \text {, } \\
\text { positive displacement chillers with leaving temperatures less than } 32^{\circ} \mathrm{F} \text {, and absorption chillers with leaving temperatures less than } 40^{\circ} \mathrm{F} \text {. }\end{array}$ & $\mathrm{R}$ \\
\hline- & $\begin{array}{l}\text { Table C403.2.3(8) Minimum efficiency } \\
\text { requirements: Heat rejection equipment }\end{array}$ & $\begin{array}{l}\text { Added a new table covering heat-rejection equipment. Four types of cooling towers are provided with minimum performance requirements in terms of gpm/hp according to } \\
\text { CTI ATC- } 105 \text { and CTI STD-201 tests. Also air-cooled condensers must meet a performance requirement in terms of Btu/h* hp according to ARI } 460 \text { test. }\end{array}$ & A \\
\hline - & Table C403.2.3(9) Heat transfer equipment & Added a new table covering plate-type liquid-to-liquid heat exchangers, referencing AHRI 400 and indicating there are no efficiency requirements. & $\mathrm{A}$ \\
\hline- & $\begin{array}{l}\text { C403.2.3.2 Positive displacement (air- and } \\
\text { water-cooled) chilling packages }\end{array}$ & Equipment with leaving fluid temperatures $>32^{\circ} \mathrm{F}$ must meet Table C403.2(7) requirements when tested or certified to a referenced test procedure. & A \\
\hline- & C403.2.4.3.3 Automatic start capabilities & $\begin{array}{l}\text { Automatic start controls are required on all HVAC systems and must adjust the daily starting time to bring all occupied spaces to desired temperature immediately before } \\
\text { scheduled occupancy. }\end{array}$ & A \\
\hline 503.2.5.1 Demand control ventilation & C403.2.5.1 Demand control ventilation & $\begin{array}{l}\text { Demand control ventilation is now required where average occupancy load is } 25 \text { people per 1,000 ft². An additional exception has been made for ventilation used only for } \\
\text { process loads. }\end{array}$ & $\mathrm{R}$ \\
\hline $\begin{array}{l}\text { 503.2.6 Energy recovery ventilation } \\
\text { system }\end{array}$ & C403.2.6 Energy recovery ventilation system & $\begin{array}{l}\text { Table 403.2.6, “Energy Recovery Requirement," has been created to define requirements for design supply air flow rates according to climate zone and percentage of } \\
\text { outdoor air at full design rates. Systems that exceed these requirements must include an energy recovery ysstem capable of changing the enthalpy of the outdoor air supply } \\
\text { by at least } 50 \% \text { of the difference between outdoor air and return air enthalpies at design conditions. Where an air economizer is required, the energy recovery system must } \\
\text { have a bypass or controls that permit the economizer to operate according to Section C403.4. Some changes have been made to Exceptions 3,5, 6, and 7, and additional } \\
\text { exceptions have been made for single exhaust locations that are below 75\% of the design rate and for systems expected to operate less than } 20 \text { hours/week while complying } \\
\text { with Table C403.2.6. }\end{array}$ & $\mathrm{R}$ \\
\hline C503.2.7.1.3 High-pressure duct systems & C403.2.7.1.3 High-pressure duct systems & 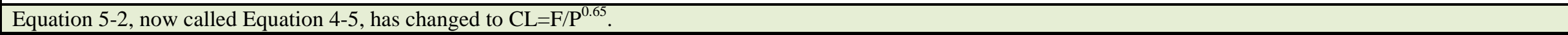 & $\mathrm{R}$ \\
\hline 503.2.8 Piping insulation & C403.2.8 Piping insulation & Changes have been made to Exceptions 3 , and 5 , and an additional exception has been made for direct buried pipe conveying fluids $\leq 60^{\circ} \mathrm{F}$. & $\mathrm{R}$ \\
\hline- & C403.2.8.1 Protection of piping insulation & Exposed piping insulation must be protected from damage from sunlight, moisture, maintenance, wind, and solar radiation. Adhesive tape is not allowed. & $\mathrm{A}$ \\
\hline Table 503.2.8 Minimum pipe insulation & $\begin{array}{l}\text { Table C403.2.8 Minimum pipe insulation } \\
\text { thickness }\end{array}$ & $\begin{array}{l}\text { This table’s format has been expanded to consider fluid operating temperature range (no longer differentiated by fluid type), conductivity, mean rating temperature, and } \\
\text { nominal pipe size (diameter). }\end{array}$ & $\mathrm{R}$ \\
\hline 503.2.9 HVAC system completion & $\begin{array}{l}\text { C403.2.9 Mechanical systems commissioning } \\
\text { and completion requirements }\end{array}$ & All of Section 503.2.9 and its subsections have been moved to Section C408.2. & $\mathrm{R}$ \\
\hline $\begin{array}{l}\text { C403.2.10.1 Allowable fan floor } \\
\text { horsepower }\end{array}$ & 503.2.10.1 Allowable fan floor horsepower & Single-zone VAV systems must comply with the constant volume fan power limitation. Exception 3 for fans that exhaust air from fume hoods has been eliminated. & $\mathrm{R}$ \\
\hline $\begin{array}{l}\text { Table 5023.2.10.1(1) Fan power } \\
\text { limitation }\end{array}$ & Table C403.2.10.1(1) Fan power limitation & Added a definition for the term $\mathrm{CFM}_{\mathrm{D}}$ that us used in determining the value of the term $\mathrm{A}$ when using Option 2 for compliance with the fan power limitation provisions. & $\mathrm{R}$ \\
\hline $\begin{array}{l}\text { Table 503.2.10.1(2) Fan power } \\
\text { limitation pressure drop adjustment }\end{array}$ & $\begin{array}{l}\text { Table C403.2.10.1(2) Fan power limitation } \\
\text { pressure drop adjustment }\end{array}$ & Several devices have been added (e.g., biosafety cabinet, coil runaround loop) and deductions have been eliminated, but the general format of this table is the same. & $\mathrm{R}$ \\
\hline $\begin{array}{l}\text { 503.3 Simple HVAC systems and } \\
\text { equipment }\end{array}$ & $\begin{array}{l}\text { C403.3 Simple HVAC systems and } \\
\text { equipment }\end{array}$ & Deleted the text indicating what the section does not apply to and referencing those named items to the section on complex HVAC systems. & $\mathrm{R}$ \\
\hline 503.3.1 Economizers & C403.3.1 Economizers & $\begin{array}{l}\text { All cooling systems with a fan must have an economizer that meets the requirements stated in Sections C403.3.1.1-C403.3.1.4. Exceptions exist for several systems (e.g., } \\
\text { systems operating }<20 \text { hours/week). }\end{array}$ & $\mathrm{R}$ \\
\hline
\end{tabular}




\begin{tabular}{|c|c|c|c|}
\hline 2009 IECC & 2012 IECC & CHANGES & $\begin{array}{l}\text { REVISION } \\
\text { TYPE }\end{array}$ \\
\hline $\begin{array}{l}\text { Table 503.3.1(1) Economizer } \\
\text { requirements }\end{array}$ & Table C403.3.1(1) Economizer requirements & $\begin{array}{l}\text { Climate Zones 2A, 7, and } 8 \text { have been moved to the category that requires an economizer, and the minimum requirement has been raised to } 54 \mathrm{~K} \text { Btu/h. The total capacity } \\
\text { for all systems without economizers has been lowered to } 300 \mathrm{~K} \text { Btu/h. }\end{array}$ & $\mathrm{R}$ \\
\hline- & C403.3.1.1 Air economizers & \begin{tabular}{|l|} 
Air economizers must comply with Sections C403.1.1.1-C403.1.1.4. \\
\end{tabular} & A \\
\hline- & C403.3.1.1.1 Design capacity & Must be able to modulate up to $100 \%$ of the design supply air as outdoor air for cooling. & $\mathrm{A}$ \\
\hline & C403.3.1.1.2 Control signal & $\begin{array}{l}\text { Dampers must be able to be sequenced with cooling equipment and not only by mixed air temperature. An exception exists for systems controlled from space temperature } \\
\text { (e.g., single-zone systems). }\end{array}$ & A \\
\hline- & C403.3.1.1.3 High-limit shutoff & $\begin{array}{l}\text { Must automatically reduce outdoor air intake to design minimum when it will no longer reduce energy usage. Table C403.3.1.1.3(1) shows the allowed and prohibited } \\
\text { control types by climate zones, and Table C403.3.1.1.3(2) shows the settings required by device type and climate zone. }\end{array}$ & A \\
\hline- & $\begin{array}{l}\text { Table C403.3.1.1.3(1) High-limit shutoff } \\
\text { control options for air economizers }\end{array}$ & Added provisions that vary by climate zone for control type acceptability in meeting the provisions requiring high-limit controls. & A \\
\hline- & $\begin{array}{l}\text { Table C403.1.1.3(2) High-limit shutoff } \\
\text { control setting for air economizers }\end{array}$ & Added provisions that vary by device type and climate zone that address the high-limit settings at which the economizer must shut off. & A \\
\hline- & C403.3.1.1.4 Relief of excess outdoor air & Systems must relieve excess outdoor air to avoid overpressurizing the building. The outlet must not recirculate air into the building. & $\mathrm{A}$ \\
\hline 503.4.1 Economizers & C403.4.1 Economizers & Sections C403.4.1.1-C403.4.1.4 have been created for these requirements. & $\mathrm{R}$ \\
\hline- & C403.4.1.1 Design capacity & $\begin{array}{l}\text { Water economizers must be able to cool by indirect evaporation and provide up to } 100 \% \text { of the cooling load at outdoor temperatures of } \leq 50^{\circ} \mathrm{F} \text { dry bulb and } \leq 45^{\circ} \mathrm{F} \text { wet } \\
\text { bulb. An exception exists for systems that cannot meet dehumidification requirements at these temperatures. For such systems, the requirements are } \leq 50{ }^{\circ} \mathrm{F} \text { dry bulb and } \\
\leq 455^{\circ} \mathrm{F} \text { wet bulb. }\end{array}$ & A \\
\hline- & C403.4.1.2 Maximum pressure drop & $\begin{array}{l}\text { Precooling coils and water-to-water heat exchangers in these systems need to have a water-side pressure drop of }<15 \mathrm{ft} \text { or a secondary loop so that pressure drop is not seen } \\
\text { by the circulating pumps in non-economizer mode. }\end{array}$ & A \\
\hline- & C403.4.1.3 Integrated economizer control & $\begin{array}{l}\text { Must be integrated with the mechanical system and able to provide partial cooling even when the mechanical system is needed. Exceptions exist for direct expansion } \\
\text { systems that reduce outdoor air to prevent coil frosting if it is no greater than } 25 \% \text { of system capacity, and for direct expansion units rated less than } 54 \mathrm{~K} \text { Btu/h that use } \\
\text { nonintegrated controls, which preclude simultaneous use of the economizer and mechanical system. }\end{array}$ & A \\
\hline- & $\begin{array}{l}\text { C403.4.1.4 Economizer heating system } \\
\text { impact }\end{array}$ & $\begin{array}{l}\text { HVAC system design and controls must not increase heating energy use. An exception exists for VAV systems that cause zone-level heating to increase due to reduced } \\
\text { supply air temperature. }\end{array}$ & A \\
\hline $\begin{array}{l}\text { 503.4.2 Variable air volume (VAV) fan } \\
\text { control }\end{array}$ & $\begin{array}{l}\text { C403.4.2 Variable air volume (VAV) fan } \\
\text { control }\end{array}$ & Requirements now apply to fans with motors $\geq 7.5 \mathrm{hp}$. The second requirement from 2009 may be replaced with a vane-axial fan with variable-pitch blades. & $\mathrm{R}$ \\
\hline- & C403.4.2.1 Static pressure sensor location & $\begin{array}{l}\text { Must be positioned so that the set point is no more than one-third of design static pressure, except for those with zone reset controls. Those downstream of duct splits must } \\
\text { have a sensor in each branch. }\end{array}$ & A \\
\hline $\begin{array}{l}\text { 503.4.2 Variable air volume (VAV) fan } \\
\text { control (second paragraph) }\end{array}$ & $\begin{array}{l}\text { C403.4.2.2 Set points for direct digital } \\
\text { control }\end{array}$ & The static pressure set point must be reset based on the zone needing the most pressure. & $\mathrm{R}$ \\
\hline 502.4.4 Hot gas bypass limitation & C403.4.7 Hot gas bypass limitations & Moved (but did not change) the hot gas bypass requirements from the envelope section of the code to the HVAC section of the code. & $\mathrm{R}$ \\
\hline 504.5 Pipe insulation & C404.5 Pipe insulation & Heat-traced systems are now included in this section and must meet the manufacturer's installation instructions. & $\mathrm{R}$ \\
\hline 504.6 Hot water system controls & C404.6 Hot water system controls & Additional wording requiring ready access to operating controls. & $\mathrm{R}$ \\
\hline 504.7 Pools & $\begin{array}{l}\text { C404.7 Pools and inground permanently } \\
\text { installed spas (Mandatory) }\end{array}$ & $\begin{array}{l}\text { This section, including the three Subsections C404.7.1-C404.7.3, remains unchanged except inground permanent spas have been added to the pool category, heaters pumps } \\
\text { and motors with built-in timers are in compliance with these codes, the R-12 requirement for covers has been eliminated, and the exception for covers now applies to those } \\
\text { receiving at least } 70 \% \text { of their energy from on-site. }\end{array}$ & $\mathrm{R}$ \\
\hline 504.7.1 Pool heaters & C404.7.1 Heaters & Change in title only from pool heaters to heaters, which according to Section C404.7 would apply to pool heaters and inground permanently installed spas. & $\mathrm{R}$ \\
\hline 504.7.3 Pool covers & C404.7.3 Covers & $\begin{array}{l}\text { Change in title from pool covers to covers, which according to Section C404.7 would apply to pools and inground permanently installed spas. The R-12 cover requirement } \\
\text { has been deleted. Changed the exception from } 60 \% \text { to } 70 \% \text { of site-recovered energy, added examples (heat pump or solar energy source) and added that the percentage } \\
\text { contribution be assessed over an operating season. }\end{array}$ & $\mathrm{R}$ \\
\hline 505.1 General (Mandatory) & C405.1 General (Mandatory) & Exception to compliance now exists only for units with $75 \%$ of permanent light fixtures having high efficacy lighting. & $\mathrm{R}$ \\
\hline- & C405.2.1 Manual lighting controls & Added a new section to refer to subsequent subsections that cover manual lighting controls. & $\bar{A}$ \\
\hline 505.2.2 Additional controls & - & $\begin{array}{l}\text { Section has been moved and renumbered due to relocation of provisions previously covered in subsections under this section (light reduction controls and automatic lighting } \\
\text { shutoff) in new subsections in the } 2012 \text { IECC). See Section C405.2.2. }\end{array}$ & $\mathrm{D}$ \\
\hline 505.2.2.1 Light reduction controls & C405.2.1.2 Light reduction controls & $\begin{array}{l}\text { Exception to compliance has undergone several changes: areas with one luminaire must have at least 100W; equipment, electrical, and mechanical rooms have been added; } \\
\text { and daylight spaces that comply with Section C405.2.2.3.2 have been added. }\end{array}$ & $\mathrm{R}$ \\
\hline 505.2.2 Additional controls & C405.2.2 Additional lighting controls & $\begin{array}{l}\text { Section reads the same as } 505.2 .2 \text { in the } 2009 \text { IECC but now refers to code provisions associated with automatic time control devices, occupancy sensors, and daylight zone } \\
\text { control. Exceptions to this section on additional lighting controls have been added and include sleeping units, spaces where patient care is directly provided, spaces where } \\
\text { automatic shutoff would impact safety or security of occupants, and where lighting must be operated continuously. }\end{array}$ & A \\
\hline 502.2.2.2.1 Occupant override & $\begin{array}{l}\text { C405.2.2.1 Automatic time switch control } \\
\text { devices }\end{array}$ & $\begin{array}{l}\text { Added new section on automatic time switch control devices and in part included the intent of 502.2.2.2.1 from the 2009 IECC. The new section indicates that all automatic } \\
\text { control devices must be installed in all buildings other than for emergency egress lighting and lighting in spaces with occupancy sensors (new text in Section C405.2.2.2). }\end{array}$ & $\mathrm{R}$ \\
\hline 502.2.2.2.2 Holiday scheduling & - & Provisions on holiday scheduling deleted. & $\mathrm{D}$ \\
\hline- & C405.2.2.2 Occupancy sensors & $\begin{array}{l}\text { Occupancy sensors are required in several specifically named types of spaces (e.g., classrooms, lunch rooms). Controls must turn off lights in rooms that are unoccupied for } \\
30 \text { minutes and must be manual on or automatically turn lighting to no more than } 50 \% \text { power. An exception exists for spaces that are used for safety and security (e.g., } \\
\text { corridors, stairways). }\end{array}$ & A \\
\hline
\end{tabular}




\begin{tabular}{|c|c|c|c|}
\hline 2009 IECC & 2012 IECC & CHANGES & $\begin{array}{l}\text { REVISION } \\
\text { TYPE } \\
\end{array}$ \\
\hline 505.2.2.3 Daylight zone control & C405.2.2.3 Daylight zone control & $\begin{array}{l}\text { Lighting in daylight zones must be controlled separately from other areas and must conform to Section C405.2.2.3.1 or C405.2.2.3.2. Daylight control zones must not be } \\
\text { greater than 2,500 } \mathrm{ft}^{2} \text {. Contiguous zones and zones under skylights still follow the } 2009 \text { IECC. }\end{array}$ & $\mathrm{R}$ \\
\hline$\overline{-}$ & C405.2.2.3.1 Manual daylighting controls & Required in daylight zones unless automatic controls are installed according to Section C405.2.2.3.2. & $\mathrm{A}$ \\
\hline- & C405.2.2.3.2 Automatic daylighting controls & $\begin{array}{l}\text { Calibrating controls (set point) must be readily accessible. Daylighting controls must either: (1) reduce lighting to less than } 35 \% \text { of rated maximum power; or (2) incorporate } \\
\text { stepped dimming such that at least one step 50-70\% of design power and another step is no greater than } 35 \% \text { of maximum power. }\end{array}$ & A \\
\hline- & C405.2.2.3.3 Multi-level lighting controls & $\begin{array}{l}\text { Added provisions for multi-level lighting controls in daylight zones to ensure that, where such controls are provided to meet the daylight zone control provisions, the general } \\
\text { lighting in the zone is separately controlled by one multi-level control that reduces space lighting power in response to daylighting. The control must also control the power } \\
\text { draw of the general lighting to no more than } 35 \% \text { of rated power when the day-lit illuminance in the space is greater than the rated illuminance of the general lighting in the } \\
\text { zone. The control must be located so calibration and set point controls are readily accessible and separate from the light sensor. }\end{array}$ & A \\
\hline 505.2.3 Sleeping unit controls & C405.2.3 Specific application controls & $\begin{array}{l}\text { Added a new section to outline situations where additional lighting controls are required. The provisions for hotel and motel sleeping units in } 505.2 .3 \text { is retained in principle } \\
\text { as item } 3 \text { in Section C405.2.3. New situations include display and accent lighting, cases used for display case purposes, supplemental task lighting, lighting for non-visual } \\
\text { applications, and lighting equipment that is for sale or demonstration. }\end{array}$ & $\mathrm{R}$ \\
\hline 505.5.2 Interior lighting power & C405.5.2 Interior lighting power & $\begin{array}{l}\text { In addition to Table C405.5.2(1), used for the building area method, a second table has been created, Table C405.5.2(2) for a space-by-space method. The approach is } \\
\text { similar, choosing the appropriate category, multiplying the given number by the floor area, and then taking the sum of all numbers. However, the second table allows for } \\
\text { specific spaces within a building type (e.g., dining areas, lobbies within a hotel). Documented justification for the need for higher power in some areas is allowed according } \\
\text { to the authority having jurisdiction. The original table has been changed slightly, but the general format remains the same. }\end{array}$ & $\mathrm{R}$ \\
\hline $\begin{array}{l}\text { Table 505.5.2 Interior lighting power } \\
\text { allowances }\end{array}$ & $\begin{array}{l}\text { Table C405.5.2(1) Interior lighting power } \\
\text { allowances: Building area method }\end{array}$ & $\begin{array}{l}\text { Footnote a to the table covering building area types and more specific building areas has been deleted and the current footnote b covering additional lighting power for retail } \\
\text { areas has been moved so it does not apply to the building area method but instead to the space-by-space method. }\end{array}$ & $\mathrm{R}$ \\
\hline 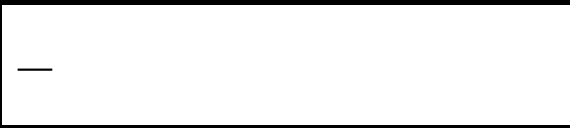 & $\begin{array}{l}\text { Table C405.5.2(2) Interior lighting power } \\
\text { allowances: Space-by-space method }\end{array}$ & $\begin{array}{l}\text { Added a new table based on ASHRAE } 90.1-10 \text { for the new space-by-space compliance method added to the code. Retained footnote 'b' covering additional lighting power } \\
\text { for retail areas from the building area method table and moved it to footnote 'a' of the space-by-space method table. Revised the footnote so the retail allowance starts at } 500 \\
\text { watts instead of } 1000 \text { watts. }\end{array}$ & A \\
\hline - & C406 Additional efficiency package options & An optional section now exists for superior performance regarding HVAC equipment, lighting, or on-site renewables. & $\mathrm{A}$ \\
\hline- & $\begin{array}{l}\text { C406.2 Efficient HVAC performance } \\
\text { Tables C406.2(1) through C406.2(7) } \\
\end{array}$ & Tables C406.2(1) through C406.2(7) will replace the tables used in Section C403 only if the efficiencies here are superior to those listen in C403. & A \\
\hline- & $\begin{array}{l}\text { C406.3 Efficient lighting system } \\
\text { C406.3.1 Reduced lighting power density }\end{array}$ & The numbers in Table C406.3 will be used in place of those in Section C405. & A \\
\hline- & C406.4 On-site renewable energy & $\begin{array}{l}\text { Minimum ratings of on-site systems must either provide } 1.75 \mathrm{BTUs} \text { or } 0.50 \mathrm{~W} / \mathrm{ft}^{2} \text { of conditioned floor area, or at least } 3 \% \text { of the energy used for mechanical equipment, } \\
\text { service hot water heating, and lighting. }\end{array}$ & A \\
\hline- & $\begin{array}{l}\text { C408 System commissioning } \\
\text { C408.1 General } \\
\end{array}$ & This entire section has been added to the previous code and applies to the commissioning of systems in Sections $\mathbf{C 4 0 3}$ and $\mathbf{C 4 0 5 .}$ & A \\
\hline- & $\begin{array}{l}\text { C408.2 Mechanical systems commissioning } \\
\text { and completion requirements }\end{array}$ & $\begin{array}{l}\text { Before completion of the final inspection, documentation must be provided with evidence of mechanical systems commissioning. Exceptions exist for systems with a } \\
\text { capacity of less than } 480 \mathrm{~K} \text { Btu/h cooling and } 600 \mathrm{~K} \text { Btu heating and for systems from Section C403.3 that serve dwelling units in hotels, motels, etc. }\end{array}$ & A \\
\hline- & C408.2.1 Commissioning plan & $\begin{array}{l}\text { Must include: (1) a narrative description of each phase of the commissioning and personnel required; (2) a list of the equipment and appliances to be tested; (3) functions } \\
\text { (e.g., calibrations) to be tested; (4) environmental conditions (e.g., seasonal) for testing; and (5) performance criteria. }\end{array}$ & A \\
\hline$\overline{-}$ & C408.2.2 Systems adjusting and balancing & HVAC systems should be balanced and adjusted within product specification tolerances. & $\mathrm{A}$ \\
\hline- & C408.2.2.1 Air systems balancing & $\begin{array}{l}\text { Supply air outlets and zone terminals must have air balancing that meets IMC Chapter } 6 \text {. Discharge dampers cannot be used with constant volume fans and VAV motors } \\
\geq 10 \text { hp. Must first minimize throttling losses then adjust fan speed to meet design conditions. An exception exists for fan motors } \leq 1 \mathrm{hp} \text {. }\end{array}$ & A \\
\hline- & C408.2.2.2 Hydronic systems balancing & $\begin{array}{l}\text { Hydronic heating and cooling coils must be used to measure flow, minimize throttle losses, and meet design flow conditions. Systems must either measure pressure across } \\
\text { the pump or test ports at each side. Exceptions exist for pump motors } \leq 5 \text { hp or where throttling is less than } 5 \% \text { of nameplate power, which is beyond a trimmed impeller. }\end{array}$ & A \\
\hline$\overline{-}$ & C408.2.3 Functional performance testing & Testing is required for equipment, controls, and economizers according to Sections C408.2.3.1-C408.2.3.3. & A \\
\hline- & C408.2.3.1 Equipment & $\begin{array}{l}\text { Must demonstrate operation of components and system-to-system interfacing according to specifications during conditions of full load, partial load, and several emergency } \\
\text { conditions (e.g., back up loads, alarms). An exception exists for equipment listed in Section C403, which do not require air economizers. }\end{array}$ & A \\
\hline$\overline{-}$ & C408.2.3.2 Controls & HVAC controls must be tested and documented to be calibrated, adjusted, and operate according to specifications. & $\mathrm{A}$ \\
\hline$\overline{-}$ & C408.2.3.3 Economizers & Must be tested to show operation in accordance with specifications. & A \\
\hline- & C408.2.4 Preliminary commissioning report & $\begin{array}{l}\text { Documented evidence of test procedures and results must be given to the building owner and must identify: (1) deficiencies that have not been corrected; (2) tests deferred } \\
\text { due to climatic conditions; and (3) climatic conditions required for deferred tests. }\end{array}$ & A \\
\hline$\overline{-}$ & C408.2.4.1 Acceptance of report & Before final mechanical inspection, a letter of receipt of the report must be given to the code official from the owner. & A \\
\hline$=$ & C408.2.4.2 Copy of report & The code official may require a copy of the code report. & A \\
\hline$=$ & C408.2.5 Documentation requirements & Construction documents must specify that the documents in this section be provided to the building owner within 90 days of the receipt of certificate of occupancy. & A \\
\hline - & C408.2.5.1 Drawings & Must include the location and performance data for all equipment. & A \\
\hline 503.2.9.3 Manuals & C408.2.5.2 Manuals & $\begin{array}{l}\text { The provisions for HVAC system manuals were deleted from the } 2009 \text { IECC and are now included in Section C408.2.5.3 of the } 2012 \text { IECC, which applies to HVAC and } \\
\text { electrical and lighting systems. }\end{array}$ & $\mathrm{R}$ \\
\hline - & C408.2.5.3 System balancing report & A written report based on the findings from Section C408.2.2. & $\mathrm{A}$ \\
\hline- & C408.2.5.4 Final commissioning report & $\begin{array}{l}\text { Must include: (1) results of performance tests; (2) deficiencies found during testing and corrective measures proposed; and (3) performance test procedures used. An } \\
\text { exception exists for test deferred due to climatic conditions. }\end{array}$ & A \\
\hline- & C408.3 Lighting system functional testing & Controls for lighting systems must comply with Section C408.3. & A \\
\hline
\end{tabular}




\begin{tabular}{|c|c|c|c|}
\hline 2009 IECC & 2012 IECC & CHANGES & $\begin{array}{l}\text { REVISION } \\
\text { TYPE } \\
\end{array}$ \\
\hline- & C408.3.1 Functional testing & $\begin{array}{l}\text { Must ensure that hardware and software function according to construction documents and manufacturer's instructions. Code official may require a third party to conduct } \\
\text { testing and provide documentation. In areas with occupancy sensors, time switches, and other procedures must confirm: (1) placement; sensitivity, and time-out adjustments } \\
\text { for sensors are acceptable; (2) time switches are programmed to turn lights off; and (3) placement and sensitivity for photo sensors reduce light based on usable daylight as } \\
\text { specified. }\end{array}$ & A \\
\hline Chapter 5 Referenced standards & Chapter 6 Referenced standards & $\begin{array}{l}\text { Updates to editions of reference standards were made in AAMA, AHRI, AMCA, ANSI, ASHRAE, ASTM, CSA, ICC, IESNA, NFRC, and WDMA standards. New } \\
\text { standards were listed for AHAM, AHRI, ASHRAE, ASTM, CTI, DASMA, DOE, and ISO. OOne standard was deleted from DOE. }\end{array}$ & $\mathrm{R}$ \\
\hline 401.2 Compliance & R401.2 Compliance & The language has been editorially changed from referencing specific section numbers to referencing provisions that are mandatory, prescriptive, and performance. & $\mathrm{R}$ \\
\hline 401.3 Certificate & R401.3 Certificate (Mandatory) & $\begin{array}{l}\text { This section has now become mandatory. The certificate must be posted by the builder or design professional and air leakage testing from duct systems and building } \\
\text { envelope are now required. }\end{array}$ & $\mathrm{R}$ \\
\hline 402.1 General (Prescriptive) & R402.1 General (Prescriptive) & Added specific text that the building thermal envelope must meet the criteria in the subsections to Section R402.1. & $\mathrm{R}$ \\
\hline $\begin{array}{l}\text { Table 402.1.1 Insulation and } \\
\text { fenestration requirements by } \\
\text { component }\end{array}$ & $\begin{array}{l}\text { Table R402.1.1 Insulation and fenestration } \\
\text { requirements by component }\end{array}$ & Some numbers and wording of footnotes have changed, but the format of the table is the same. & $\mathrm{R}$ \\
\hline Table 402.1.3 Equivalent U-factors & Table R402.1.3 Equivalent U-factors & Some numbers and wording of footnotes have changed, but the format of the table is the same. & $\mathrm{R}$ \\
\hline $\begin{array}{l}\text { 402.2 Specific insulation requirements } \\
\text { (Prescriptive) }\end{array}$ & $\begin{array}{l}\begin{array}{l}\text { R402.1 Specific insulation requirements } \\
\text { (Prescriptive) }\end{array} \\
\end{array}$ & $\begin{array}{l}\text { Added specific text that clarifies that the insulation must meet the thermal envelope provisions as well as all the specific insulation requirements outlined in subsections to } \\
\text { Section R402.2. }\end{array}$ & $\mathrm{R}$ \\
\hline- & R402.2.3 Eave baffle & $\begin{array}{l}\text { If an attic is vented and has air permeable insulation, it must have a baffle adjacent to soffit and eave vents that is no less in size than the vent itself and must extend over top } \\
\text { of the insulation. }\end{array}$ & A \\
\hline $\begin{array}{l}\text { 402.2.5 Steel-frame ceilings, walls, and } \\
\text { floors }\end{array}$ & $\begin{array}{l}\text { R402.2.6 Steel-frame ceilings, walls, and } \\
\text { floors }\end{array}$ & Deleted the exception that allowed the recution of continuous insulation on steel-framed wall assemblies in Climate Zones 1 and 2. & $\mathrm{R}$ \\
\hline $\begin{array}{l}\text { Table 402.2.5 Steel-frame ceiling, wall, } \\
\text { and floor insulation (R-value) }\end{array}$ & $\begin{array}{l}\text { Table R402.2.6 Steel-frame ceiling, wall, and } \\
\text { floor insulation (R-value) }\end{array}$ & Steel-framed walls have been divided into two categories, 16 in. O.C. and 24 in. O.C., having separate requirements for each. The rest of the table is unchanged. & $\mathrm{R}$ \\
\hline ( & R402.2.12 Sunroom insulation & $\begin{array}{l}\text { Sunrooms enclosing conditioned spaces must comply with this code. For sunrooms with thermal isolation, the ceiling R-values need only be R-19 in Climate Zones 1-4 and } \\
\text { R-24 in Climate Zones 5-8; wall R-values need only be R-13 in all climate zones. }\end{array}$ & A \\
\hline $\begin{array}{l}\text { 402.3.5 Thermally isolated sunroom U- } \\
\text { factor }\end{array}$ & R402.3.5 Sunroom U-factor & $\begin{array}{l}\text { Sunrooms enclosing conditioned space must comply with this code. Exceptions exist in Climate Zones } 4-8 \text { such that the U-factor must be } \leq 0.45 \text { and the skylight U-factor } \\
\text { must be } \leq 0.75 \text {. }\end{array}$ & $\mathrm{R}$ \\
\hline 402.4 Air leakage (Mandatory) & R402.4 Air leakage (Mandatory) & The 2009 IECC had no text in this section. Text has been added to indicate that the provisions of all subsections to Section R402.4 must be satisfied. & $\mathrm{R}$ \\
\hline 402.4.1 Building thermal envelope & R402.4.1 Building thermal envelope & $\begin{array}{l}\text { The provisions of the code have been deleted, other than the requirement associated with dissimilar material expansion and contraction, and replaced with a reference to the } \\
\text { provisions in the two subsections that address installation and testing. }\end{array}$ & $\mathrm{R}$ \\
\hline $\begin{array}{l}\text { Table 402.4.2 Air barrier and insulation } \\
\text { inspection component criteria }\end{array}$ & $\begin{array}{l}\text { Table R402.4.1 Air barrier and insulation } \\
\text { installation }\end{array}$ & One category (common wall) has been added and several changes have been made to the criteria, including a footnote. All other formatting remains the same. & $\mathrm{R}$ \\
\hline 402.4.2.2 Visual inspection option & R402.4.1.1 Installation & $\begin{array}{l}\text { The provisions of the code have been relocated. While the wording has been revised, the intent is to ensure application of the provisions in the table on air barrier and } \\
\text { insulation installation. Unlike the } 2009 \text { IECC, these provisions must be satisfied in all cases (see Section R402.4). }\end{array}$ & $\mathrm{R}$ \\
\hline 402.4.2.1 Testing option & R402.4.1.2 Testing & $\begin{array}{l}\text { This section is now mandatory. Air changes per hour must not exceed five in Climate Zones } 1 \text { and 2, and must not exceed three in all others. The conditions of testing have } \\
\text { undergone slight modification but are essentially the same except that the condition that HVAC ducts not be sealed has been removed. }\end{array}$ & $\mathrm{R}$ \\
\hline 402.4.2.2 Visual option & - & This section has been removed. & $\mathrm{D}$ \\
\hline 402.4.3 Fireplaces & R402.4.2 Fireplaces & \begin{tabular}{|l|l} 
New wood-burning fireplaces now require tight-fitting flue dampers rather than gasketed doors. \\
\end{tabular} & $\mathrm{R}$ \\
\hline 402.4.5 Recessed lighting & R402.4.4 Recessed lighting & The wording has been edited to provide the air leakage rate limit first, followed by the test standard instead of the test standard first, followed by the air leakage rate limit. & $\mathrm{R}$ \\
\hline 403.2 Ducts & 403.2 Ducts & The 2009 IECC had no text in this section. Text has been added to indicate that the provisions of all Section R403.2 subsections must be satisfied. & $\mathrm{R}$ \\
\hline 403.2.2 Sealing (Mandatory) & R403.2.2 Sealing (Mandatory) & $\begin{array}{l}\text { Exceptions have now been made such that (1) air-impermeable spray foam products are permitted without joint seals; (2) for inaccessible duct connections, three rivets will } \\
\text { be spaced on the exposed joint; and (3) continuously welded and locking longitudinal joints and seams in ducts operating at } 500 \text { Pa do not require additional closure } \\
\text { systems. Also, leakage must be } \leq 4 \mathrm{cfm} / 100 \mathrm{ft} \text { of conditioned floor area for both the preconstruction and rough-in test and for the rough-in test the leakage is } \leq 3 \mathrm{cfm} / 100 \mathrm{ft}{ }^{2} \\
\text { of conditioned floor area if the air handler is not installed. This test is not required if air handlers and ducts are entirely within conditioned space. }\end{array}$ & $\mathrm{R}$ \\
\hline$\overline{-}$ & R403.2.2.1 Sealed air handler & Air handlers must have a manufacturer's air leakage of $\leq 2 \%$ of design air flow rate when tested to ASHRAE 193. & A \\
\hline$\overline{-}$ & R403.3.1 Protection of piping insulation & Exposed insulation must be protected from damage (e.g., from sunlight, moisture, maintenance). Adhesive tape is not permitted. & A \\
\hline- & R403.4 Service hot water systems & $\begin{array}{l}\text { New provisions have been added to distinguish provisions for pipe insulation and circulating systems as applying to service hot water systems (see Sections R403.4.1 and } \\
\text { R403.4.2). }\end{array}$ & A \\
\hline $\begin{array}{l}\text { 403.4 Circulating hot water systems } \\
\text { (Mandatory) }\end{array}$ & $\begin{array}{l}\text { R403.4.1 Circulating how water systems } \\
\text { (Mandatory) }\end{array}$ & The provision concerning R-2 insulation has been deleted (see Section R403.4.2). The code now only addresses controls as covered in the previous code requirements. & $\mathrm{R}$ \\
\hline 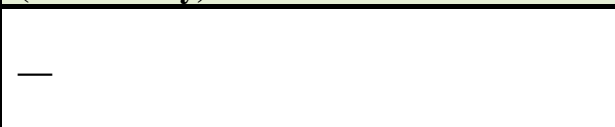 & $\begin{array}{l}\text { R403.4.2 Hot water pipe insulation } \\
\text { (Prescriptive) }\end{array}$ & $\begin{array}{l}\text { R-3 insulation is required with hot water piping for the following piping: (1) 34-in. diameter; (2) serving more than one dwelling unit; (3) from water heater to kitchen } \\
\text { outlets; (4) outside conditioned space; (5) from water heater to distribution manifold; (6) under floor slab; (7) buried piping; (8) supply and return recirculation other than } \\
\text { demand recirculation; and (9) having greater run lengths than the distance specified in Table R403.4.2. }\end{array}$ & A \\
\hline- & Table R403.4.2 Maximum run length & $\begin{array}{l}\text { A new table has been added providing pipe lengths as a function of pipe diameter over which R-3 pipe insulation is required unless the pipe's location or function is } \\
\text { specifically listed in Section R403.4.2. }\end{array}$ & A \\
\hline
\end{tabular}




\begin{tabular}{|c|c|c|c|}
\hline 2009 IECC & 2012 IECC & CHANGES & $\begin{array}{l}\text { REVISION } \\
\text { TYPE }\end{array}$ \\
\hline $\begin{array}{l}\text { 403.5 Mechanical ventilation } \\
\text { (Mandatory) }\end{array}$ & R403.5 Mechanical ventilation (Mandatory) & Must now meet the requirements of IRC or IMC or with other approved means of ventilation. & $\mathrm{R}$ \\
\hline 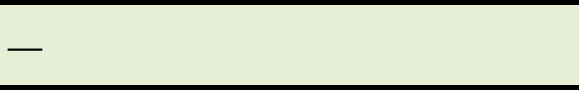 & $\begin{array}{l}\text { R403.5.1 Whole-house mechanical } \\
\text { ventilation system fan efficiency }\end{array}$ & Must meet the requirements of Table 403.5.1. An exception exists for fans integral to tested and listed HVAC systems, which must have an electrically commutated motor. & A \\
\hline- & $\begin{array}{l}\text { Table R403.5.1 Mechanical ventilation } \\
\text { system fan efficiency }\end{array}$ & $\begin{array}{l}\text { Added new provisions (see Section R403.5.1) for minimum fan efficiency in cfm/watt by fan location (e.g., range, in-line, bathroom, utility room) as a function of } \\
\text { minimum and maximum fan air flow rate. }\end{array}$ & A \\
\hline 403.6 Equipment sizing (Mandatory) & R403.6 Equipment sizing (Mandatory) & Must be done in accordance with ACCA Manual S based on loads calculated in Manual J or other approved methods. & $\mathrm{R}$ \\
\hline 403.9.3 Pool covers & R403.9.3 Pool covers & Minimum R-12 values are not required. An exception exists for pools receiving $>70 \%$ of their energy from site-recovered sources. & $\mathrm{R}$ \\
\hline 404.1 Lighting (Prescriptive) & R404.1 Lighting (Mandatory) & This section is now mandatory. At least $75 \%$ of all fixtures must be high efficacy. An exception exists for low-voltage fixtures. & $\overline{\mathrm{R}}$ \\
\hline- & R404.1.1 Lighting equipment (Mandatory) & Fuel gas lighting may not have continuous pilot lights. & $\mathrm{A}$ \\
\hline 405.4 Documentation & R405.4 Documentation & Text has been included in the 2012 IECC to specifically refer to and require compliance with subsections to this section of the code. & $\mathrm{R}$ \\
\hline 405.5 Calculation procedure & R405.5 Calculation procedure & Text has been included in the 2012 IECC to specifically refer to and require compliance with subsections to this section of the code. & $\mathrm{R}$ \\
\hline 405.6 Calculation software tools & R405.6 Calculation software tools & Text has been included in the 2012 IECC to specifically refer to and require compliance with subsections to this section of the code. & $\mathrm{R}$ \\
\hline 405.6.1 Minimum capabilities & R405.6.1 Minimum capabilities & Calculation of whole-building sizing for heating and cooling equipment is now in accordance with the standard reference design in Section R403.6. & $\mathrm{R}$ \\
\hline $\begin{array}{l}\text { Table 405.5.2(1) Specifications for the } \\
\text { standard reference and proposed } \\
\text { designs }\end{array}$ & $\begin{array}{l}\text { Table 405.5.2(1) Specifications for the } \\
\text { standard reference and proposed designs }\end{array}$ & $\begin{array}{l}\text { Revisions have been made to the table for interior shade fraction, the air-exchange rate, heating systems, cooling systems, and thermal distribution systems. Footnotes to the } \\
\text { table have also been revised to reflect changes to the table. }\end{array}$ & $\mathrm{R}$ \\
\hline Chapter 5 Referenced standards & Chapter 6 Referenced standards & $\begin{array}{l}\text { Updates to editions of reference standards were made in AAMA, ASHRAE, CSA, ICC, NFRC, and WDMA standards. New standards were listed for ACCA and ASHRAE. } \\
\text { Standards were deleted from ASHRAE and ASTM. }\end{array}$ & $\mathrm{R}$ \\
\hline
\end{tabular}






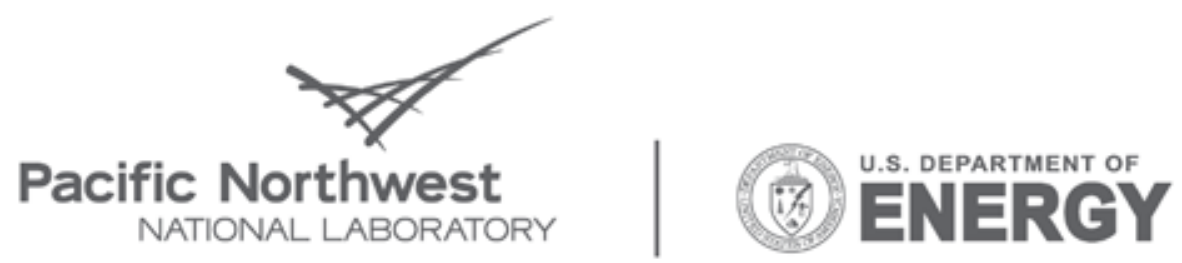

Proudly Operated by Battelle Since 1965

902 Battelle Boulevard

P.O. Box 999

Richland, WA 99352

1-888-375-PNNL (7665)

www.pnl.gov 